\title{
A New Lining Material for Aluminum Electrolysis Cells
}

ISSN: 2578-0255

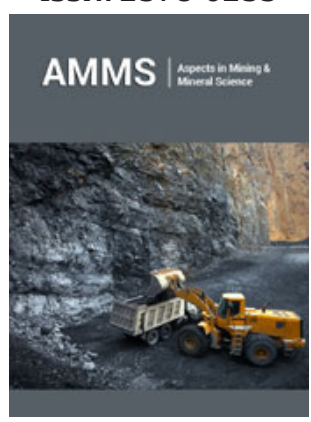

*Corresponding author: Aleksandr V Proshkin, Head, Cathode Technology Department, UC RUSAL Engineering \& Technology Centre, Krasnoyarsk, Russia

Submission: 蹓 February 10, 2020

Published: 䀝February 19, 2020

Volume 4 - Issue 3

How to cite this article: Aleksandr $\mathrm{V}$ Proshkin*, Aleksey S Zherdev, Aleksandr V Popov. A New Lining Material for Aluminum Electrolysis Cells. Aspects Min Miner Sci.4(3). AMMS.000589.2020.

DOI: 10.31031/AMMS.2020.04.000589

Copyright@ Aleksandr V Proshkin, This article is distributed under the terms of the Creative Commons Attribution 4.0 International License, which permits unrestricted use and redistribution provided that the original author and source are credited.

\author{
Aleksandr V Proshkin*, Aleksey S Zherdev and Aleksandr V Popov \\ ${ }^{1}$ Head, Laboratory of Carbon Materials, Russia \\ ${ }^{2}$ Director, Department of New Technologies, Russia \\ ${ }^{3}$ Head, Cathode Technology Department, Russia
}

\section{Opinion}

The world's amount of SPL in the existing dumps is several tens of millions of tones and increases by $1.7 \mathrm{M}$ tones annually [1]. About $30 \%$ of this material is spent aluminosilicate refractory and insulating materials. A significant number of publications cover different methods to dispose and recycle such materials [2-5]. However, so far, the value of the regenerated product has not exceeded the cost of processing, and there is no cost-effective and environmentally friendly solution of this problem, yet. One of the possible solutions is the use of semi-coke of lignite as an insulation and, partially, refractory material, including its subsequent recycling. At an industrial level, semi-coke of lignite is produced by the oxidizing carbonization of low-ash, low-sulfur coal in the boiler, including fluidized bed combustion at temperatures of $700-800{ }^{\circ} \mathrm{C}[6]$. This allows generating flammable gases and a solid product with a low volatile content. The product of pyrolysis lignite -the semi coke -has a dull gray or blackish color and a highly porous structure. The studies showed that more than $90 \%$ of the mass of the initial semi-coke of lignite was in a substantially amorphous state. Refractory and heat-insulating products in the form of bricks of various sizes are traditionally used in the installation of aluminum electrolytic cells. The low impermeability of the masonry due to inter-brick seams, the relatively high cost, high labor costs and the lack of the possibility of their reuse after service due to their inevitable destruction during dismantling are the disadvantages of such materials and the technologies for their use. Unshaped refractory materials of various particle size and mineralogical compositions, which are in a dispersed state, are largely devoid of such drawbacks. The manufacturing technology of such materials requires 2-3 times less floor space and is characterized by higher productivity (4-5 times) and 5-6 times less energy consumption. The test results of unshaped barrier materials based on olivine showed a decrease in service life, which cast doubt on the appropriateness of their use as barrier materials [5]. At the same time, the successful use of predominantly aluminosilicate unformed lining materials is confirmed by world practice data [7]. The average life of Chinese electrolytic cells at $300 \mathrm{kA}$, the installation of which was carried out using dry barrier mixtures (DBM), is 2,200 days.

An analysis of current trends in the development of the processing of waste lining materials in both ferrous and non-ferrous metallurgy shows that the most effective method of processing is their reuse (recycling). One of the possible types of unformed materials to replace both heat-insulating and partially refractory material with the possibility of recycling is lignite coal semi-coke (LSC) - a product of brown coal pyrolysis. For more than 10 years, RUSAL has conducted laboratory and industrial tests of lining materials based on LSC. The studies have shown that the use of the product of pyrolysis of lignite (semi-coke) as an insulating and, partially, refractory material for the cell's cathode is motivated by such properties as low thermal conductivity, high chemical stability (both with respect to sodium and the combined effect of fluorides, aluminum and sodium). It has been shown that lignite semi-coke may be used as a lining material for the under-cathode area of the cell. Original installation by compacting of unshaped refractory materials is developed. Equipment for installation and recycling, as well as technology for their application, has been developed. 
At present, RUSAL successfully operates more than 1000 cells from materials based on lignite semi coke. Equipment for the use of unformed lining materials provides high-quality cathode designs. Autopsy results for cells with a life of about 1000 days show that $80 \%$ of the new lining material can be reused, which improves both environmental safety and the economic efficiency of aluminum production. In contrast to the existing processes, the proposed approach is simple and accessible; given the low cost and the possibility of recycling, this approach is also highly efficient from an economic point of view. Using a new un-shaped material - the lignite semi-coke - opens the door to the mechanization and automation of the process of assembling and disassembling cathodes, including a significant reduction in labor costs and time, and, in the meantime, the improvement of the quality of the process of lining. This allows a highly efficient use of the material. The technology, which uses lignite semi-coke, allows having an economic effect by virtue of the following: reduction of the cost of lining materials; reduction of labor costs during installation; reduction of the amount of waste; and the reduction of fees for the storage of waste (possibility to recycle).

\section{References}

1. Morten Sørlie, Harald Øye (2010) Cathodes in aluminum electrolysis. $\left(3^{\text {rd }}\right.$ edn), Aluminum-Verlag GmbH, Düsseldorf, Germany, p. 662.

2. Brooks DG, Cutshall ER, Banker DB, Strahan DF (1992) Thermal treatment of spent potliner in a rotary kiln. Light Metals pp. 283-287.

3. Wangxing Li, Xiping Chen (2006) Running results of the SPL detoxifying pilot plant in Chalco. Light Metals pp. 219-225.

4. Sturm E, Prepeneit J, Sahling M (2002) Economic and environmental aspects of an effective diffusion barrier. Light Metals pp. 433-437.

5. Bruna Meireless, Henrique Santos (2014) Economic and environmental alternative for destination of spent pot lining from primary aluminum production. Light Metals pp. 565-570.

6. Islamov S (2007) About the new concept of use of coal. Coal 5: 67-69.

7. Jeltsch R, Cairong C (2012) Dry barrier mix in reduction cell cathodes. Light Metals pp. 1259-1263. 